\title{
Antimicrobial and anti-inflammatory activities of Apis mellifera honey on the Helicobacter pylori infection of Wistar rats gastric mucosa
}

\author{
Thiago Yamamoto AMARAL ${ }^{1,2}$, Igor Gomes PADILHA ${ }^{1,2}$, Gustavo Alvares PRESÍDIO ${ }^{1,2}$, \\ Edmo Arruda Aguiar Sobreira da SILVEIRA ${ }^{1,2}$, Alysson Wagner Fernandes DUARTE ${ }^{1,3}$, \\ Ana Paula Fernandes BARBOSA ${ }^{1,2}$, Antônio Fernando de Souza BEZERRA ${ }^{1,2}$, Ana Maria Queijeiro LÓPEZ ${ }^{1,2 *}$
}

\begin{abstract}
Considering that Helicobacter pylori, a bacterium able to colonize the upper gastrointestinal tract and cause mucosal injury, not always can be effectively eradicated by the traditional approaches, there is an interest in alternative therapies until a vaccine be available. Honey is a food supplement with high carbohydrate content and antioxidant activity, as well as broad antimicrobial spectrum. After analyzing the physicochemical and in vitro antimicrobial properties of an Apis mellifera honey from the Atlantic forest of Alagoas / Brazil, the purpose of the present work was evaluate its in vivo effects against Helicobacter pylori in the gastric mucosa of Wistar rats. First, it was verified the success of inoculation/infection of the pathogen in the gastric mucosa of the rats, through the subsequent removal of their stomachs for histological analysis (hematoxylin and eosin stain and Giemsa stain). Then, four groups of animals were treated with sterilized distilled deionized water, the Apis mellifera honey, a combination of omeprazole, amoxicillin and clarithromycin, and an association of such medicines and honey (1:1). Except the control, all treatments were effective in combating infection, however, honey reduced the inflammatory process, whilst the antibiotics increase the number of eosinophils.
\end{abstract}

Keywords: gastritis; peptic ulcer; antioxidant; anti-inflammatories; antibiotic.

Practical Application: Control of bacterial contamination using functional food.

\section{Introduction}

The bacterium called Helicobacter pylori is a Gram-negative spirillum which colonizes the upper gastrointestinal tract specifically the stomach, of approximately $50 \%$ of the world's population (Salama et al., 2013). Infection with $H$. pylori causes chronic inflammation and significantly increases the risk of developing duodenal and gastric ulcers, being the strongest known factor to initiate gastric cancer, which is the second type of cancer that kills more worldwide (Wroblewski et al., 2010; Graham, 2015).

Since Warren \& Marshall (1983) identified H. pylori for the first time as a pathogen, through gastric endoscopy in patients with gastritis and ulcers, the paradigms about the sterility of the stomach changed. After that, the medical community understood that $H$. pylori, but not stress, could be the major cause of stomach inflammation, which, in some cases, precedes peptic ulcer disease (10\%-20\%), distal gastric adenocarcinoma (1\%-2\%) and the gastric MALT (mucosal-associated lymphoid tissue)-lymphoma $(<1 \%)$. Then, the identification of this pathogen and its accumulated evidences as an important factor to gastric carcinogenesis were significant progresses in this cancer etiology (Dorer et al., 2009; Wroblewski et al., 2010; Graham, 2015).
Approximately half of the world's population is infected with $\mathrm{H}$. pylori, and the majority (80\%) of colonized individuals does not show any symptoms and develop coexisting chronic inflammation. However, long-term carriage of $H$. pylori significantly increases the risk of developing site-specific diseases such as cancer (Saha et al., 2009; Wroblewski et al., 2010).

Studies of the gastric mucosa in high risk populations have revealed a series of lesions which, sequentially, evolve from normal condition to chronic non-atrophic gastritis (CNAG), which would progress to atrophic gastritis $(\mathrm{AG})$ and intestinal metaplasia (IM) and, eventually, to dysplasia and adenocarcinoma (Nakamura et al., 2002; Hartgrink et al., 2009). Once H. pylori chronically colonize the gastric environment, it persists for the lifetime of the host, suggesting that the host immune response is ineffective in clearing this bacterium. In addition to the effects of the host and responses, $H$. pylori strains are genetically diverse, with different degrees of virulence and clinical outcomes, increasing risk for developing gastric cancer (Wroblewski et al., 2010), but it is not clear why some strains are associated with ulcer formation with relevant clinical symptoms, while others are asymptomatic (Saha et al., 2009; Wroblewski et al., 2010). 
Despite the consolidated use of antibiotics and a proton pump inhibitor in the treatment against $H$. pylori, it is observed that neither medicines are always efficient since the antibiotics resistance has increased amongst the pathogen strains. Therefore, considering the level of efficiency, its high cost and side effects related, several researches have been carried out on natural products, either of vegetal or animal origin, aiming the detection and characterization of chemical compounds with antimicrobial and anti-inflammatory properties (Carson \& Riley, 2003; Bonacorsi et al., 2009; Ayala et al., 2014). Plant and honey extracts are among the most attractive sources of new drugs and have shown promising results in gastric ulcer treatment, whose reduction rate, from the beginning of the treatment, serves as a marker of cure (Bonacorsi et al., 2009; Keenan et al., 2010).

Honey is a food supplement which currently has received an increment in commercial consumption, mainly due to the scientific validation of its several beneficial properties to health (Keenan et al., 2010). Such nutraceutical product presents high carbohydrate content, elevated antioxidant activity, as well as expressive antimicrobial activity; it has already been tested in vitro against $H$. pylori, showing an activity more efficient than some antibiotics commonly indicated (Duarte, 2009; Ayala et al., 2014). Besides the nutritional properties, therefore, the use of honey in popular medicine is due to its pharmacological properties, which raises interest among researchers because of its potential applicability in clinical cases (Carson \& Riley, 2003).

Thus, the purpose of this research is to evaluate the effects of the direct inoculation of $H$. pylori on the gastric mucosa of
Wistar rats, and analyze in vivo and in vitro the antimicrobial and antioxidant properties of honey from different floral origins. For this, a physical-chemical analysis of the selected honey samples was also carried out.

\section{Materials and methods}

\subsection{Honey sample and its flavonoid/phenolic acids analysis}

The honey sample used here was one (M8) amongst others subjects of a previous study on the palynological/geographical origin of honeys harvested during the dried season in the State of Alagoas (Northeastern Brazil), and their chemical composition and antioxidant/antimicrobial activity in vitro. The pollen analysis of its apiary showed that it was mainly produced from flowers of Erythrina velutina and Mimosa spp., and it was selected due to its high inhibitory activity of $H$. pylori in vitro, as well as its elevated antioxidant activity and high contents of total phenolics such as flavonoids (Figure 1).

The following physicochemical parameters were evaluated in triplicate: moisture (Association of Official Analytical Chemists, 1997); $\mathrm{pH}$, free acidity, contents of total and reducing glycides and apparent sucrose (Vargas, 2006); electrical conductivity, contents of proline and hydroxy-methyl-furfural (HMF) (Bogdanov et al., 1999); content of total proteins (Lowry et al., 1951); diastase activity (Santos et al., 2003); color (Bianchi, 1989); total phenolic content (Meda et al., 2005); total flavonoid content (Al et al., 2009).<smiles>O=C(O)c1cc(O)c(O)c(O)c1</smiles><smiles>COc1cc(C(=O)O)ccc1O</smiles>

Vanillic acid

Benzoic acids

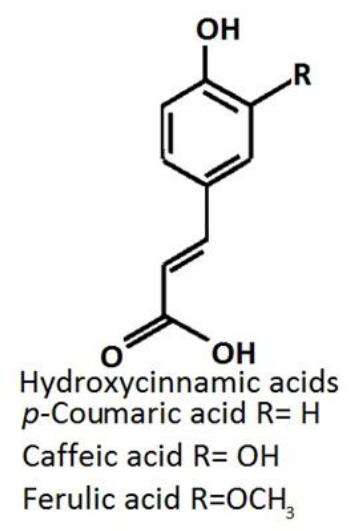

Ellagic acid

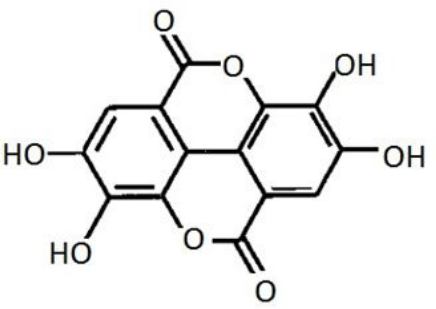

Ferulic acid $\mathrm{R}=\mathrm{OCH}_{3}$

p-Hydroxybenzoic acid

Hydroxybenzoid acids

Figure 1. Phenolics and flavonoids present in Apis mellifera honey from Atlantic Forest of the State of Alagoas (Northeastern Brazil), during the dried season. 
Besides this, a chromatographic analysis was done with the extract, to identify the mainly phenolic and flavonoids. Thereafter, a volume containing $50 \mathrm{~g}$ of this sample was thoroughly mixed, under agitation and at room temperature, with $250 \mathrm{~mL}$ of sterilized distilled deionized water (SDDW), and its $\mathrm{pH}$ was adjusted to $\mathrm{pH} 2$ with concentrated $\mathrm{HCl}$, until completely fluid and homogenized. Then, the solution was filtered through cotton wool and mixed with $75 \mathrm{~g}$ Amberlite XAD-2 (pore size $9 \mathrm{~nm}$, particle size $0.3-1.2 \mathrm{~mm}$ ) under $10 \mathrm{~min}$ of agitation. The Amberlite particles with the phenolic compounds from the honey were packed in a glass column $(42 \times 3.2 \mathrm{~cm})$ and this was first eluted with acidified water ( $\mathrm{pH} 2$ with $\mathrm{HCl}, 125 \mathrm{~mL}$ ) and then with SDDW $(150 \mathrm{~mL})$ to remove all carbohydrates and other polar constituents of honey. The phenolic compounds were eluted with methanol $(200 \mathrm{~mL})$, concentrated to dryness in a roto-evaporator $\left(40^{\circ} \mathrm{C}\right)$, re-suspended in SDDW $(5 \mathrm{~mL})$ and extracted with diethyl ether $(5 \mathrm{~mL})$. The diethyl ether was removed by flushing the volume in a test tube with nitrogen gas, and the residue re-solubilized in $1 \mathrm{~mL}$ of methanol, filtered through a $0.22 \mu \mathrm{m}$ membrane filter, and analyzed by high performance liquid chromatography (HPLC), using a Shimadzu Prominence LG2OAT HPLC equipped with a photodiode array detector (SPDM2O) and a reversed-phase column (Shimpack CLC-ODS, $4.6 \mathrm{~mm} \times 250 \mathrm{~mm} \times 5 \mu \mathrm{m}$ ). For the benzoic and cinnamic acid derivatives, the mobile phase consisted of a mixture of $5 \%$ aqueous formic acid (A) and methanol (B) at a flow rate of $1 \mathrm{~mL} / \mathrm{min}$. A gradient elution was used, starting with $20 \% \mathrm{~B}$ up to $15 \mathrm{~min}, 30 \% \mathrm{~B}$ at $20 \mathrm{~min}, 40 \% \mathrm{~B}$ at $30 \mathrm{~min}$ and isocratic at $40 \% \mathrm{~B}$ up to $45 \mathrm{~min}$. The flavonoids were separated using a mobile phase consisting of $1 \%$ aqueous formic acid (A) and methanol (B) at a flow rate of $1 \mathrm{~mL} / \mathrm{min}$ and the following gradient: 0-3 min $40 \%$ B, 5-15 min 45\% B, 17-25 min 50\% B, $27-35 \min 55 \% \mathrm{~B}$, and $35-40 \mathrm{~min} 70 \% \mathrm{~B}$. The injection volume was $10 \mu \mathrm{L}$. They were quantified by their absorbance in the HPLC chromatograms against external standards [naringerin at $290 \mathrm{~nm}$ (for flavanone), isorhametin, myrcetin, kaempferol and quercetin at $340 \mathrm{~nm}$ (3-hydroxyflavones or flavonol-aglycones)], and phenolic acids, such as caffeic, chlorogenic, gallic, vanillic, 3,4-dihydroxybenzoic and $p$-coumaric acids, were quantified against their standards at $290 \mathrm{~nm}$. Ellagic acid was quantified against its standard at $340 \mathrm{~nm}$. Analyses were performed by plotting a calibration curve for each flavonoid/ phenolic methanolic solution $(0.5-5.0 \mathrm{mg} / \mathrm{mL})$, which were then correlated with the measured area.

\subsection{Animals, bacterium and inoculation}

Adult healthy female Wistar rats Rattus norvegicus (Berkenhout, 1769) (Rodentia: Muridae), weighing ca. $300 \mathrm{~g}$ (80 days-old) were provided by the "Central Biotery" of the Federal University of Alagoas (UFAL - 016713/2009-83). They were kept at controlled temperature $\left(25 \pm 2{ }^{\circ} \mathrm{C}\right)$ and light regimen (light cycle from 7 a.m. to 7 p.m.), inside standard polypropylene appropriate cages (maximum 4 animals in each) sanitized every two days, with diary substitution of filtered water (ad libitum) and standard rat $\operatorname{diet}$ (Nuvilab CR1, Brazil), always under continuous veterinary supervision. The assays were performed after all the experimental protocols have been approved by the institutional "Committee of Ethical in Animal Research" (CEPA) from UFAL.
The lyophilized strain of $H$. pylori ATCC 43504 was provided by "Oswaldo Cruz Foundation-RJ". It was activated on Agar Nutrient and incubated anaerobically for $24 \mathrm{~h}$ at $36^{\circ} \mathrm{C}$. Then, the cells were washed with SDDW, and the inoculation in animals was done using the aqueous suspension containing $10^{8}$ cells. $\mathrm{mL}^{-1}$. For this, it was used an orogastric tube adapted to a sterile syringe, which was introduced in the gastric mucosa of healthy female Wistar rats, studied as described below. So, the occurrence of infection was observed, as well as the outbreak of alterations in the gastric mucosa (ulcers, erosions and gastric neoplasia).

\subsection{Monitoring infection process}

Sixteen healthy adult female Wistar rats (80 days-old, approximately $300 \mathrm{~g}$ of mass) were provided and maintained as above mentioned, in accordance with the instructions given by the institutional CEPA-UFAL. The experimental design considered two equal groups (8 animals each). In the "control" group, $1 \mathrm{~mL}$ of SDDW was introduced in the stomach of each rat at the first day of the experiment. In the "pilot" group, this volume of SDDW was replaced by an aqueous suspension of $H$. pylori cells, prepared as previously described.

After 30 days submitted to the same environmental, sanitary and feeding conditions, prior to inoculation, a rat from the "pilot" group was randomly selected and subjected to exploratory laparotomy, to assess whether the stomach mucosa was infected. Thus, the animal was anesthetized with $1 \mathrm{~mL}$ of a mixture of equal parts of Xylestesine and Ketamine. After the retroperitoneal injection of the anesthetic, as soon as the animal did not react to external stimuli, it was attached to a board using medical tape and the surgical act was performed through a xyfopubic incision using scalpel, scissors and rat-tooth forceps, until the stomach be found in the abdominal cavity. The clamping using Hartmann ${ }^{\circledR}$ forceps in its front and back region was necessary to avoid a hemorrhagic process. The surgical act ended with the sacrifice of the animal, deepening the anesthetic in the same proportion previously cited, until the cardiac arrest was observed. The surgical remains, as well as the carcass of the referred animal, were buried in an appropriate place next to the surgery laboratory.

To observe the extirpated stomachs, they were placed on trays of Styrofoam (previously covered with graph paper- $\mathrm{mm}$ ), opened through the great curvature with a scissors-made incision, from the antrum to the pylorus, and affixed with pins to be stretched out as much as possible (respecting the elasticity and friability of the tissue). After that, the material was immersed in $10 \%$ formaldehyde for 30 days (fixation), and excised in 4 regular square parts, which underwent the paraffin inclusion. These 4 blocks were sectioned ( $\cong 5 \mu \mathrm{m}$ thick) onto glass slides in a horizontal way and the cuts immersed over nigh $\left(\right.$ at $40^{\circ} \mathrm{C}$ ) in albumin solution before being stained by hematoxylin-eosin ( $\mathrm{H} \& \mathrm{E})$ or Giemsa methods (Boldt et al., 2015). The stained sections were analyzed under light microscopy $(400 \times$ or $1000 \times$ magnification - the last one under oil immersion objective) to find colonization of the cells. Once the infection was evidenced, the other rats belonging 
to the "control" and the "pilot" groups were maintained alive for further 50 days, under the same environmental, nutritional and sanitary conditions of the beginning of the studies, before being subjected to the same sort of procedures. The goal was to evaluate, after that time, not only the infection of the gastric mucosa, but also the appearance of alterations such as ulcers, erosions and neoplasia.

\subsection{Evaluation of anti-ulcer activity}

In the second stage, the experimental design considered 4 treatments to which the 32 rats were subjected, namely: 1) therapy only with SDDW ("control" group - “C”); 2) traditional therapy with an aqueous solution of Omeprazole (40 mg/day) + amoxicillin (1500 mg/day) + clarithromycin (400 mg/day) ("Medicine" group - M); 3) alternative therapy based on Africanized bee honey from the Atlantic Brazilian Forest (apiary "Princesa das Matas", Viçosa, Alagoas) ("Honey" group - H); 4) therapy with an association of the medicines referred in "2" plus the honey used in " 3 " in a proportion 1:1 v/v ("Medicine + Honey” group - MH).

Then, each group of 8 female rats ( 80 days-old), were maintained and inoculated as described above ("pilot" group) for the first experiment. After 60 days, every 72 hours for more 16 days, the rats were force-feeding with $1 \mathrm{~mL}$ of the specific therapy, using an inox gavage cannula. The quality safety and composition of the honey used in this work was previously analyzed, as soon as it was harvested, in September/2009 (Duarte, 2009; Duarte et al., 2012).

Once all the treatments had been carried out, the animals underwent anesthesia and surgical removal of their stomach, which were excised, fixed, included in paraffin, sectioned, stained and macro and microscopically analyzed as previously described.

\subsection{Scoring gastric inflammation/lesion}

Besides the detection of infection by H. pylori in the tissue, architecture, kind and degree of inflammatory infiltrate, and presence of degeneration and regeneration of the epithelial cells lining were analyzed using the classification scale of the Sydney System (Jones et al., 2002; Nakamura et al., 2002). This classification scale is based on endoscopic and histopathologic criteria, emphasizing etiology, topography and morphology with degrees of inflammation $[0=$ (absent $) ;+$ (discreet $) ;++$ (moderate); +++ (high)]. The quantification of $H$. pylori infection was also subjective, having been attributed a scoring: $0=$ absence of $H$. pylori; $1=$ discreet presence of $H$. pylori in up to 5 glands; $2=$ moderate presence of $H$. pylori in 6 to 10 glands; $3=$ high presence of $H$. pylori in 11 glands or more.

\subsection{Statistical analysis}

The physicochemical results are expressed as averages \pm SD (standard deviation) of triplicates, and statistical difference was tested by using one-way analysis of variance (ANOVA). Differences on the histology score were tested by the Mann-Whitney $U$ test. Both tests considered the results as statistically significant when $\mathrm{p}<0.05$.

\section{Results and discussion}

The chemical analysis of the sample M8 of Apis mellifera honey (Table 1), harvested in an apiary of the Atlantic Forest of Alagoas (Brazil), showed that it is rich in phenolic and flavonoid compounds and has a high antioxidant activity. Spectrophotometry methods typically reported higher levels of phenolic compounds in honeys than those determined by HPLC, probably due to the presence of nonphenolic components that can react with the same reagent as them, interfering in the spectrophotometric analysis and overestimating concentrations, as suggested by Escarpa \& Gonzalez (2001). Ellagic acid (Figure 1) recorded the highest concentration among the phenolic acids, while Kampferol recorded the higher level among the flavonoids (Table 1). The honey sample also presents an in vitro activity against $H$. pylori (Table 2 ) higher than Norfloxacin $(10 \mu \mathrm{g})$.

Although macroscopically ulcers, erosions and malign gastric neoplasia were not present, the mucosa glands of antrum and gastric body of the stomachs of the first lot of Wistar rats showed colonization by $H$. pylori, stimulating the continuation of the study. In the second stage, the control group (animals treated only with sterilized water) showed infection and moderate inflammatory process in the gastric mucosa, exactly the opposite seen in the group treated with honey (Figures 2 and 3 ). The medicines combination, however, avoided the infection, but not the inflammatory process (higher number of eosinophils on this tissue in comparison with the other, which may be related to allergic response to the administrated drugs - Table 3, Figure 2). The stomach tissues of the animals treated with the association of drugs and honey $(1: 1 \mathrm{v} / \mathrm{v})$ inhibited the colonization by $H$. pylori but reduced the inflammatory process (Table 3, Figure 2).

In the "control" group, the antrum gastric mucosa of the rats showed a higher inflammatory potential in relation to the body mucosa, confirming similar studies in humans (Manyi-Loh et al., 2010). In Brazil, ca. $80 \%$ of the cases of gastritis are associated to $H$. pylori, with variable degrees of inflammation, activity, cell proliferation, degenerative alterations, edema, congestion and erosions, all progressing strongly with the age, it means, in middle-aged adults only few of these inflammatory signals of gastritis associated to $H$. pylori can be detected.

The same was seen in this study, once the rats presented chronological age compatible with middle-aged human adults and the infection/inflammation signals were not so severe. On the other hand, in the treatments using honey the sample, similar results were seen when comparing the responses of the antrum with the gastric body (Table 3 ), and in both, the inflammatory process and the activity of the bacterium decreased.

Although the number of animals available for the present study was limited to advanced statistical analyses, and the test model did not delve into the mechanisms of action, it is possible to compare the present results with others already obtained in studies of the action of general phenols and flavonoids, or even other samples of honey. It has been hypothesized that honey's healing effect on wounds of rodents and humans may in part be due to its antioxidant, antibacterial and anti-inflammatory effects (Van den Berg et al., 2008), based on the effect of honey or parts of its constituents on mediators of inflammation. 
Table 1. Physicochemical parameters and total phenolic, flavonoids and antioxidant activity of an Apis mellifera honey sample harvest (dry season) in the Atlantic Forest (Viçosa, Al-Brazil).

\begin{tabular}{|c|c|}
\hline Characteristic & Average \pm SD \\
\hline Moisture (\%) & $18.50 \pm 0.20$ \\
\hline$\left[\mathbf{H}^{+}\right]$ & $3.185 \times 10^{-7} \pm 1.696 \times 10^{-7}$ \\
\hline$(\mathrm{pH})$ & $6.50-6.77$ \\
\hline Acidity $\left(\right.$ meq $\left.\mathrm{Kg}^{-1}\right)$ & $7.20 \pm 0.13$ \\
\hline Electrical conductivity $\left(\mathrm{mS} . \mathrm{cm}^{-1}\right)$ & $0.57 \pm 0.02$ \\
\hline Total Proteins (mg.100g $\left.{ }^{-1}\right)$ & $6.76 \pm 0.32$ \\
\hline Proline (mg.100g $\left.\mathrm{g}^{-1}\right)$ & $71.92 \pm 079$ \\
\hline Total Reducing Carbohydrates (\%) & $76.21 \pm 1.41$ \\
\hline Total carbohydrates (\%) & $72.23 \pm 0.47$ \\
\hline Sucrose $(\%)$ & $5.72 \pm 0.27$ \\
\hline Diastasis (G) & $12.45 \pm 0.26$ \\
\hline Hydroxymethylfurfural (mg. Kg $\left.{ }^{-1}\right)$ & $34.40 \pm 1.14$ \\
\hline Color (mm Pfund) & $46.61 \pm 0.42$ \\
\hline Total Phenolic (eq mg gallic acid . 100g ${ }^{-1}$ ) (Spectrophotometric method) & $101.39 \pm 1.69$ \\
\hline Total Flavonoids (eq mg quercetine $.100 \mathrm{~g}^{-1}$ ) (Spectrophotometric method) & $29.19 \pm 1.58$ \\
\hline Antioxidant Activity (eq mg quercetine. $100 \mathrm{~g}^{-1}$ ) & $11.50 \pm 0.98$ \\
\hline Antioxidant Activity (eq mg gallic ac. $100 \mathrm{~g}^{-1}$ ) & $9.16 \pm 0.46$ \\
\hline \multicolumn{2}{|l|}{ Simple Phenolic/ Flavonoids (mg. 100g ${ }^{-1}$ (HPLC) } \\
\hline Gallic acid & 0.082 \\
\hline Vanillic acid & 0.031 \\
\hline 3,4-di-hydroxybenzoic acid & 0.053 \\
\hline$p$-coumaric acid & 0.046 \\
\hline ellagic acid & 0.244 \\
\hline kaempferol & 0.370 \\
\hline isoquercitin & 0.118 \\
\hline isorhamnetin & 0.093 \\
\hline myrcitin & 0.065 \\
\hline naringenin & 0.239 \\
\hline quercetin & 0.177 \\
\hline
\end{tabular}

Table 2. Helicobacter pylori growth inhibition in vitro by different antibiotic and concentrations of Apis mellifera honey (harvested in Atlantic Forest of Viçosa, Alagoas, during the dry season).

\begin{tabular}{lc}
\hline \multicolumn{1}{c}{ Tested products } & $\begin{array}{c}\text { Inhibition } \\
\text { halos (mm) }\end{array}$ \\
\hline Aqueous solution of honey from Apis mellifera 25\% & $42.50 \pm 0.00$ \\
Aqueous solution of honey from Apis mellifera 15\% & $38.55 \pm 0.63$ \\
Cotrimoxazole $25 \mu \mathrm{g}$ & $48.50 \pm 3.53$ \\
Norfloxacin $10 \mu \mathrm{g}$ & $30.57 \pm 1.58$ \\
\hline
\end{tabular}

In the present study, it was certified the efficiency of the honey treatment against infection, possibly because of its high glucose concentration, which can be oxidized by the glucose-oxidase, leading to the production of hydrogen peroxide, and this acts against the bacterium. Also, the acidity, low protein content and osmolality contribute to the antimicrobial effect of different honeys, as studied by Manyi-Loh et al. (2010). In addition, according to Gharzouli et al. (2002), the oral administration of honey hyperosmotic solutions increases the endogen prostacyclin in both antral and body mucosa of rats, optimizing cytoprotection and reducing the luminal pathogen population. Furthermore, the secretion of non-sulfhydryl proteins and endogen nitric acid by tissues treated by honey, and the high contents of phenolics/flavonoids in such nutraceutical supplement, which can clean the free superoxide and other oxygen reactive species (liberated during the respiratory explosion of the mucosa cells infected by $H$. pylori), helping in the protection of the mucin producing cells of the stomach, as well as acting as scavengers of nitric oxide, also contribute to its therapeutic potential (Gharzouli et al., 2002; Bonacorsi et al., 2009; Owoyele et al., 2011).

The drug-therapy traditionally used in humans against $H$. pylori infection is efficient, and this was also verified in the gastric mucosa of Wistar rats. Amoxicillin (penicillin) prevents the final stage of the synthesis of the external cell membrane of Gram negative bacteria, whilst Omeprazole is a gastric inhibitor of the $\mathrm{K}^{+}$-ATPase proton pump, and Clarithromycin (tetracycline) penetrates the Gram-negative bacteria (passive diffusion/ transport through the hydrophilic porins), and inhibits its protein synthesis binding the $30 \mathrm{~S}$ ribosome subunit (Hartgrink et al., 2009). However, when this therapy was used here, with a dose-concentration adjusted to the weight of the rats (ca. $300 \mathrm{~g}$ ), an inflammatory process was provoked in rats, possibly depending on the kind of immune dysregulation involved and able to activated the cascade of inflammatory cytokines, and related to their gastric intrinsic adverse effects, also common in humans, such as vomit, diarrhea, nausea (Carson \& Riley, 2003). 

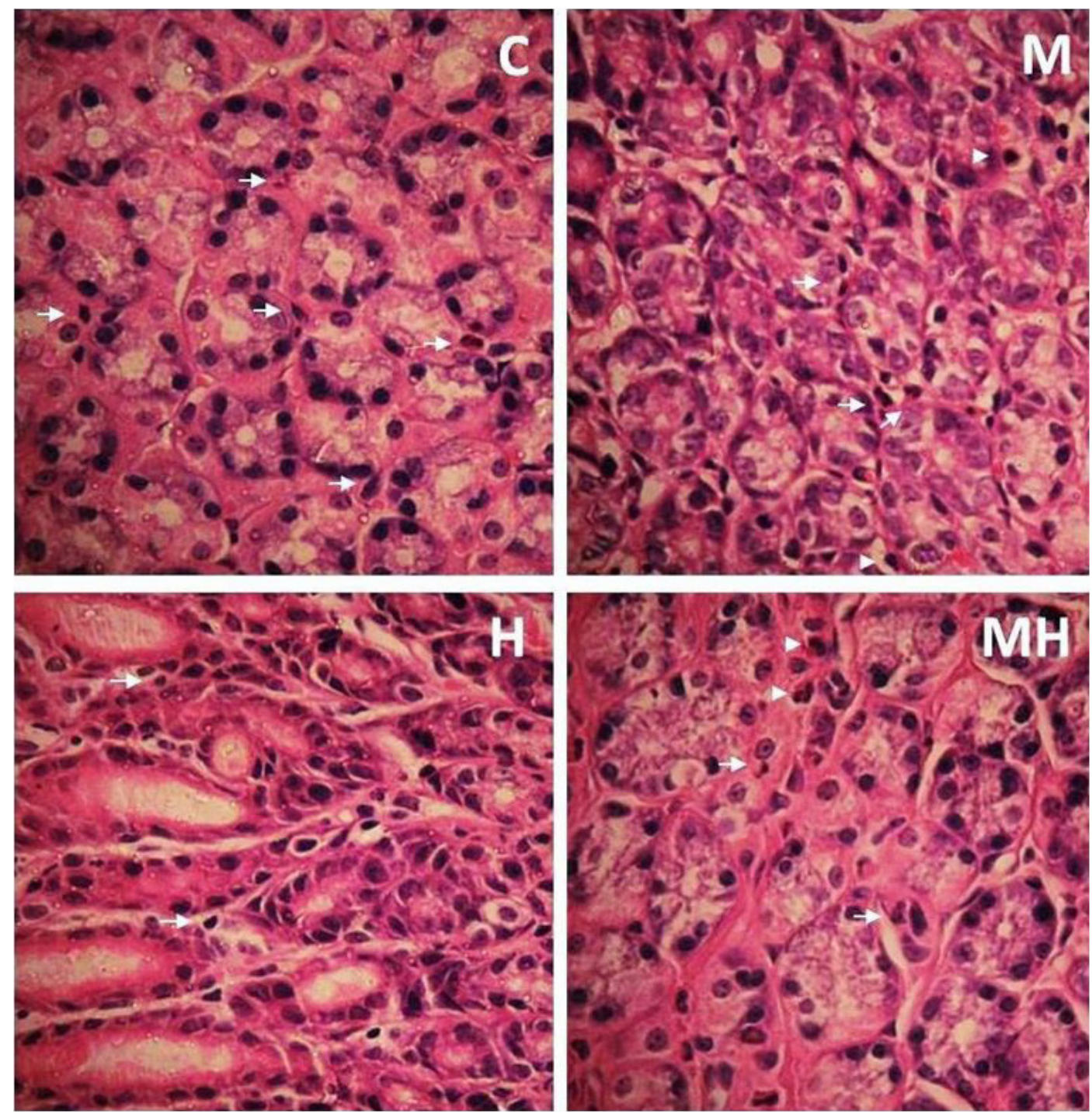

Figure 2. Light microscopy (640×, H\&E stain) from gastric mucosa (stomach) of Wistar rats infected with Helicobacter pylori after treatment $(\mathrm{C}=$ control; $\mathrm{H}=$ honey; $\mathrm{M}=$ medicines; $\mathrm{MH}=$ medicines + honey). Arrows shows gastritis. $(\mathrm{C} \rightarrow$ Gastritis active; $\mathrm{M}, \mathrm{MH} \rightarrow \mathrm{increase}$ of the eosinophils probable due to hypersensitivity caused by antibiotics).
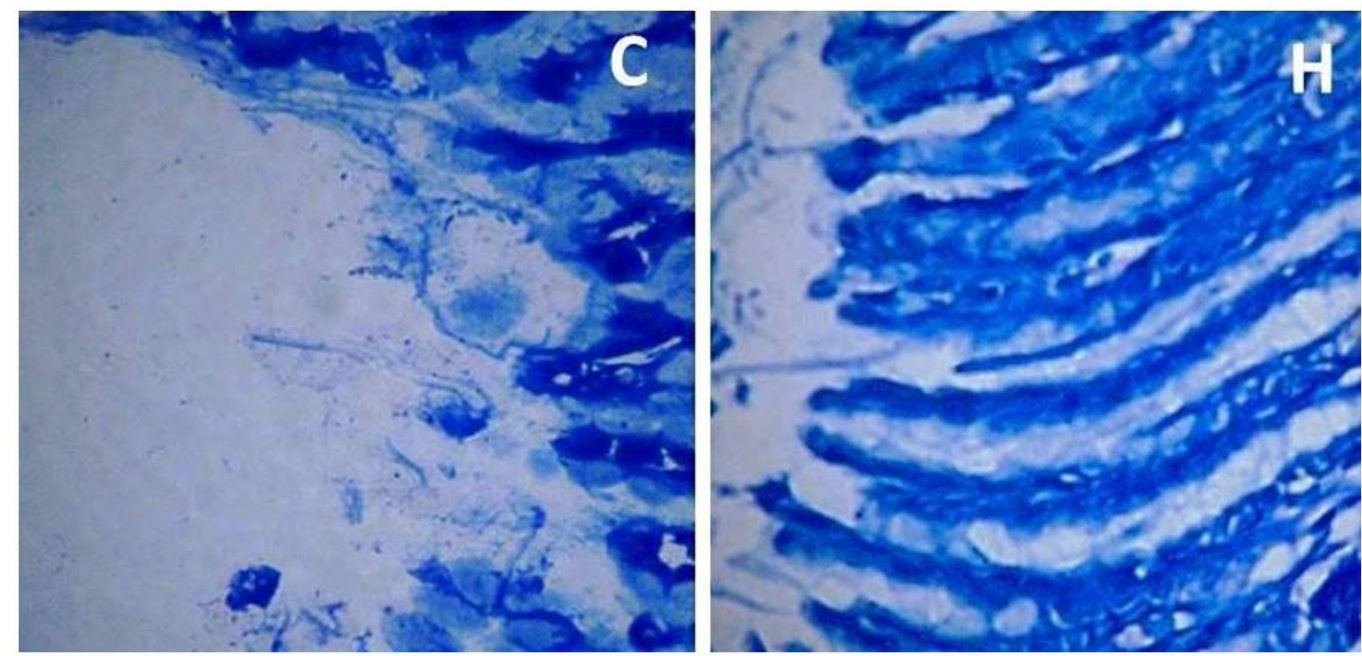

Figure 3. Light microscopy $(1000 \times$, Giemsa stain) from gastric mucosa of Wistar rats infected by Helicobacter pylori before treatment $(\mathrm{C}=$ control $\rightarrow$ infection; $\mathrm{H}=$ honey $\rightarrow$ no infection $)$. 
Table 3. Presence of Helicobacter pylory, inflammation and activity in the gastric mucosa of body and antrum regions of the Wistar rats stomach, according to the Sydney System classification scale $(\varnothing=$ Absent, $+=$ Low, $++=$ Moderate, $+++=$ Severe $)$.

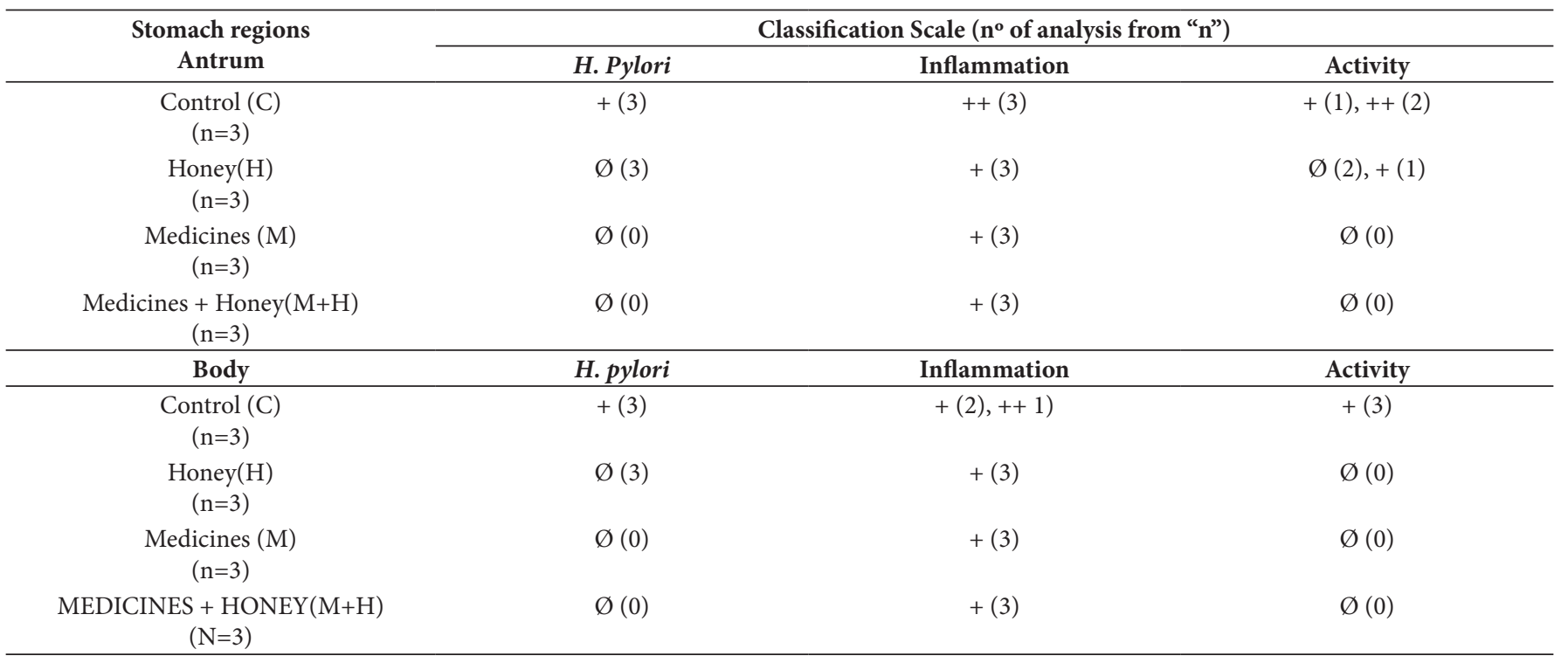

\section{Conclusion}

The present data points to the promising role of a nutritional approach using Apis mellifera honey, from the Atlantic Forest of Alagoas, rich in antioxidant phenolics/flavonoids, in the control of $H$. pylori infection, once it inhibits deleterious inflammation of gastric mucosa of Wistar rats, while an effective vaccine against this bacterium is not available.

\section{Acknowledgements}

To the apiary "Princesa das Matas" (Viçosa-Alagoas), the "Central Biotery-UFAL" and the "Oswaldo Cruz Foundation-RJ", for providing respectively the honey sample, animals and strain of H. pylori used in this research. To the Professor Dr. Lucy V.S. Lima (Faculty of Medicine-UFAL), for allowing the use of the "Laboratory of Animal Experimentation". To the Brazilian agencies "BNB", "CNPQ" and "FAPEAL", respectively for the grant support (1950/004-2007) and scholarships of the first five authors.

\section{References}

Al, M. L., Daniel, D., Moise, A., Bobis, A., Laslo, L., \& Bogdanov, S. (2009). Physicochemical and bioactive properties of different floral origin honeys from Romania. Food Chemistry, 112(4), 863-867. http://dx.doi.org/10.1016/j.foodchem.2008.06.055.

Association of Official Analytical Chemists - AOAC. (1997). Official methods of analysis. Washington: AOAC.

Ayala, G., Escobedo-Hinojosa, W. I., Cruz-Herrera, C. F., \& Romero, I. (2014). Exploring alternative treatments for Helicobacter pylori infection. World Journal of Gastroenterology, 20(6), 1450-1469. PMid:24587621. http://dx.doi.org/10.3748/wjg.v20.i6.1450.

Bianchi, E. M. (1989). La miel, caracteristicas y composición: análisis y adulteraciónes. Santiago Del Estero: Unse, CEDIA.

Bogdanov, S., Lüllmann, C., Martin, P., von der Ohe, W., Russmann, H., Vorwohl, G., Oddo, L. P., Sabatini, A.-G., Marcazzan, G. L., Piro,
R., Flamini, C., Morlot, M., Lhéritier, J., Borneck, R., Marioleas, P., Tsigouri, A., Kerkvliet, J., Ortiz, A., Ivanov, T., D’Arcy, B., Mossel, B., \& Vit, P. (1999). Honey quality and international regulatory standards: a review by the International Honey Commission. Bee World, 80(2), 61-69. http://dx.doi.org/10.1080/0005772X.1999.11099428.

Boldt, M. S., Pereira, R. D., \& Barbosa, A. J. A. (2015). Identificação histológica do H. pylori corado por hematoxilina-eosina e Giemsa: revisão para controle de qualidade. Jornal Brasileiro de Patologia e Medicina Laboratorial, 51(2), 108-112. http://dx.doi.org/10.5935/16762444.20150019.

Bonacorsi, C., Raddi, M. S. G., Carlos, I. Z., Sannomiya, M., \& Vilegas, W. (2009). Anti-Helicobacter pylori activity and immunostimulatory effect of extracts from Byrsonima crassa Nied. (Malpighiaceae). BMC Complementary and Alternative Medicine, 9(2), 2-7. PMid:19149866.

Carson, C. F., \& Riley, T. V. (2003). Non-antibiotic therapies for infectious diseases. Communicable Diseases Intelligence, 27(Suppl), 143-146. PMid:12807291.

Dorer, M. S., Talarico, S., \& Salama, N. R. (2009). Helicobacter pylori's unconventional role in health and disease. PLoS Pathogens, 5(10), e1000544. PMid:19855816. http://dx.doi.org/10.1371/journal. ppat.1000544.

Duarte, A. W. F. (2009). Mel de abelhas nativas e africanizadas do Estado de Alagoas: composição química, segurança microbiológica e atividade terapêutica (Master's dissertation). Alagoas: Universidade Federal de Alagoas.

Duarte, A. W. F., Santos Vasconcelos, M. R., Menezes, A. P. D., Silva, S. C., Oda-souza, M., \& López, A. M. Q. (2012). Composition and antioxidant activity of honey from Africanized and stingless bees in Alagoas (Brazil): a multivariate analysis. Journal of Apicultural Research, 51(1), 23-35. http://dx.doi.org/10.3896/IBRA.1.51.1.04.

Escarpa, A., \& Gonzalez, M. C. (2001). Approach to the content of total extractable phenolic compounds from different food samples by comparison of chromatographic and spectrophotometric methods. Analytica Chimica Acta, 427(1), 119-127. http://dx.doi.org/10.1016/ S0003-2670(00)01188-0.

Gharzouli, K., Amira, S., Gharzouli, A., \& Khennouf, S. (2002). Gastro protective effects of honey and glucose-fructose-sucrose-maltose 
mixture against ethanol-, indomethacin-, and acidified aspirininduced lesions in the rat. Experimental and Toxicologic Pathology, 54(3), 217-221. PMid:12484559. http://dx.doi.org/10.1078/09402993-00255.

Graham, D. Y. (2015). Helicobacter pylori Update: Gastric Cancer, Reliable Therapy, and Possible Benefits. Gastroenterology, 148(4), 719-731. PMid:25655557. http://dx.doi.org/10.1053/j.gastro.2015.01.040.

Hartgrink, H. H., Jansen, E. P., Van Grieken, N. C., \& Van de Velde, C. (2009). Gastric cancer. Lancet, 374(9688), 477-490. PMid:19625077. http://dx.doi.org/10.1016/S0140-6736(09)60617-6.

Jones, N. L., Day, A. S., Jennings, H., Shannon, P. T., Galindo-Mata, E., \& Sherman, P. M. (2002). Enhanced disease severity in Helicobacter pylori-infected mice deficient in Fas signaling. Infection and Immunity, 70(5), 2591-2597. PMid:11953400. http://dx.doi.org/10.1128/ IAI.70.5.2591-2597.2002.

Keenan, J. I., Salm, N., Hampton, M. B., \& Wallace, A. J. (2010). Individual and combined effects of foods on Helicobacter pylori growth. Phytotherapy Research, 24(8), 1229-1233. PMid:20658571.

Lowry, O. H., Rosebrough, N. J., Farr, A. L., \& Randall, R. J. (1951). Protein measurement with the Folin phenol reagent. The Journal of Biological Chemistry, 193(1), 265-275. PMid:14907713.

Manyi-Loh, C. E., Clarke, A. M., Munzhelele, T., Green, E., Mkwetshana, N. F., \& Ndip, R. N. (2010). Selected South African honeys and their extracts possess in vitro anti-Helicobacter pylori activity. Archives of Medical Research, 41(5), 324-331. PMid:20851288. http://dx.doi. org/10.1016/j.arcmed.2010.08.002.

Meda, A., Lamien, C. E., Romito, M., Millogo, J., \& Nacoulma, O. G. (2005). Determination of the total phenolic, flavonoid and proline contents in Burkina Fasan honey, as well as their radical scavenging activity. Food Chemistry, 91(3), 571-577. http://dx.doi.org/10.1016/j. foodchem.2004.10.006.

Nakamura, M., Haruma, K., Kamada, T., Mihara, M., Yoshihara, M., Sumioka, M., Fukuhara, T., \& Chayama, K. (2002). Cigarette smoking promotes atrophic gastritis in Helicobacter pylori-positive subjects.
Digestive Diseases and Sciences, 47(3), 675-681. PMid:11911358. http://dx.doi.org/10.1023/A:1017901110580.

Owoyele, B. V., Adenekan, O. T., \& Soladoye, A. O. (2011). Effects of honey on inflammation and nitric oxide production in Wistar rats. Journal of Chinese Integrative Medicine, 9(4), 447-452. PMid:21486559. http://dx.doi.org/10.3736/jcim20110415.

Saha, D. R., Datta, S., Chattopadhyay, S., Patra, R., De, R., Rajendran, K., Chowdhury, A., Ramamurthy, T., \& Mukhopadhyay, A. K. (2009). Indistinguishable cellular changes in gastric mucosa between Helicobacter pylori infected asymptomatic tribal and duodenal ulcer patients. World Journal of Gastroenterology, 15(9), 1105-1112. PMid:19266604. http://dx.doi.org/10.3748/wjg.15.1105.

Salama, N. R., Hartung, M. L., \& Muller, A. (2013). Life in the human stomach: persistence strategies of the bacterial pathogen Helicobacter pylori. Nature Reviews. Microbiology, 11(6), 385-399. PMid:23652324. http://dx.doi.org/10.1038/nrmicro3016.

Santos, K. S., Malaspinas, O., \& Palmas, M. S. (2003). Kinetics of diástase in honey of different floral origin. Mensagem Doce, 70, 2-4.

Van den Berg, A. J., Van den Worm, E., Van Ufford, H. C., Halkes, S. B., Hoekstra, M. J., \& Beukelman, C. J. (2008). An in vitro examination of the antioxidant and anti-inflammatory properties of buckwheat honey. Journal of Wound Care, 17(4), 172-174. PMid:18494436. http://dx.doi.org/10.12968/jowc.2008.17.4.28839.

Vargas, T. (2006). Evaluation of the quality of honey produced in the general fields of Paraná (Master's dissertation). Paraná: Universidade Estadual de Ponta Grossa.

Warren, J. R., \& Marshall, B. (1983). Unidentified curved bacilli on gastric epithelium in active chronic gastritis. Lancet, 1(8336), 1273 1275. PMid:6134060.

Wroblewski, L. E., Peek, R. M. Jr, \& Wilson, K. T. (2010). Helicobacter pylori and gastric cancer: factors that modulate disease risk. Clinical Microbiology Reviews, 23(4), 713-739. PMid:20930071. http://dx.doi. org/10.1128/CMR.00011-10. 